\title{
Meta-Analysis: The Effect of Breast Milk on Child Language
}

\author{
Liza Laela Abida'), Bhisma Murti'), Hanung Prasetya ${ }^{2)}$ \\ 1)Masters Program in Public Health, Universitas Sebelas Maret \\ ${ }^{2)}$ Study Program of Acupunture, School of Health Polytechnics, Ministry of Health, Surakarta
}

\section{ABSTRACT}

Background: Language development is an individual's ability to master vocabulary, speech, grammar, and pronunciation ethics within a certain period of time according to age development. Breast milk is the best food for babies, because it contains all the nutrients needed in the right amount to promote a child's growth and development. The purpose of this study was to analyze the effect of breastfeeding on children's language development by using meta-analysis.

Subjects and Method: This was a systematic review and meta-analysis. The articles used in this study were obtained from several databases including PubMed, Google Scholar, and Springer Link. The articles used in this study were those published from 1999-2020. The article search was carried out by considering the eligibility criteria defined using the PICO model. The population in the study were children aged 2 months to 6 years old with intervention in the form of receiving breast milk, the comparison was that the outcome was not given breast milk in the form of language development. Keywords for searching articles are as follows: "language development" AND "breast- feeding" OR "breastmilk" AND "child" AND "observational". The articles included in this study are full text articles with an observational study design. Articles were collected using PRISMA flow diagrams. Articles were analyzed using the Review Manager 5.3 application.

Results: A total of 11 articles were reviewed in this study. Meta-analysis of 7 cohort studies showed that breast milk improved children's language development $(\mathrm{aOR}=1.19 ; 95 \% \mathrm{CI}=$ 0.82 to $1.73 ; \mathrm{p}=0.35$ ). Meta-analysis of 4 crosssectional studies showed that breast milk improved children's language development $(\mathrm{aOR}=1.54 ; 95 \% \mathrm{CI}=0.72$ to $3.30 ; \mathrm{p}=0.27)$.

Conclusion: Language development improved children's language development.

Keywords: breastfeeding, breastmilk, language development

\section{Correspondence:}

Liza Laela Abida. Masters Program in Public Health. Universitas Sebelas Maret, Jl. Ir. Sutami 36A, Surakarta 57126, Central Java. Email: lizalaela@gmail.com. Mobile: 085640115633.

Cite this as:

Abida LL, Murti B, Prasetya H (2020). Meta-Analysis:The Effect of Breast Milk on Child Language. J Matern Child Health. 05(05): 579-589. https://doi.org/10.26911/thejmch.2020.05.05.11.

cc (i) (-) Journal of Maternal and Child Health is licensed under a Creative Commons EY NC SA Attribution-NonCommercial-ShareAlike 4.0 International License.

\section{BACKGROUND}

Language development is an individual's ability to master vocabulary, speech, grammar, and pronunciation ethics within a certain period of time according to age development (Yusuf, 2004). A person can be said to have mastered the language if he/she has mastered the five components of the language itself, namely phonology, morphology, syntax, semantics, and pragmatics (ASHA, 2020).

One of the important aspects in the development of children's language is breast milk because it contains unsaturated fats that can be absorbed by the baby's digestion and is very good for metabolism in the growth and development of children (Iqbal et al., 2017). 
Based on the Basic Health Research (2018) in Indonesia, it shows that exclusive breastfeeding has only reached $37.3 \%$. The number of primary studies examining the effect of breastfeeding on children's language development has encouraged the researchers to carry out more comprehensive study from these primary studies. The data obtained will be analyzed using a systematic review and meta-analysis by synthesizing the results of studies conducted to reduce bias.

\section{SUBJECTS AND METHOD}

\section{Study Design}

This studyis a systematic and meta-analysis review. The articles used in this study were obtained from several databases including PubMed, Google Scholar, and Springer Link. The keywords for finding articles are as follows: "language development" AND " breastfeeding" OR "breastmilk" AND "child" AND "observational".

\section{Inclusion Criteria}

The articles included in this study are full paper articles with an observational study design, in Indonesian and English. Appropriate articles should mention breast-fed interventions with the outcome of language development.

The article uses the appropriate population i.e. children aged 2 months to 6 years old. The analysis used is the multivariate adjusted Odds Ratio.

\section{Exclusion Criteria}

The articles published in this study are articles that have been carried out by metaanalysis. Articles published before 1999 and artiket are not multivariate.

\section{Operational definition of variables}

The article search was conducted by considering the eligibility criteria defined using the PICO model. Population in children aged 2 months to 6 years old with intervention in the form of being given breast milk, comparison that was not received breast milk and outcomes in the form of language development.

Language development is an individual's ability to master vocabulary, speech, grammar, and pronunciation ethics within a certain period of time according to age development (Yusuf, 2004).

Breast milk is the best and natural food for babies. Breast milk is the best food for babies in early life, this is because breast milk can protect babies from infection. Breastfeeding saves about 1.5 million babies per year in developing countries (Ministry of Health, 2008).

According to Iqbal et al. (2017), children who were breastfed for more than 6 months found that their language skills were $95.3 \%$ and their cognitive abilities were $93.7 \%$. This is different from children who are breastfed for less than 6 months where the results of children's language skills are only $88.6 \%$ and cognitive abilities are only $86.4 \%$.

\section{Data Analysis}

Data processing was carried out by the Review Manager (RevMan 5.3) by calculating the effect size and heterogeneity to determine the study model that was combined and formed the final meta-analysis result.

\section{RESULTS}

The process of searching for articles by searching through databases with journals can be seen in Figure 1. Figure 2 shows the areas where articles were taken according to the inclusion criteria. Articles obtained from 4 continents, namely Asia, America, Europe and Australia.

Based on the results of the forest plot (Figure 3) in the cohort study, breastfeeding increased language development in children by 1.19 times higher compared to non-breastfeeding which was statistically 
significant $(\mathrm{p}=0.35)$. The heterogeneity of the research data showed $\mathrm{I}^{2}=77 \%$. Meanwhile, in a cross-sectional study, breastfeeding increased language development in children by 1.54 times higher compared to not breastfed and it was statistically significant $(p=0.27)$. The heterogeneity of the study data showed $I^{2}=60 \%$. So that the distribution of data was declared heterogeneous (random effect model).

The funnel plot (figure 4) is characterized by asymmetry of the right and left plots where 5 plots are on the left and 6 plots are on the right. The plot on the left of the graph have a standard error between 0 and 1 and the plot on the right has a standard error between 0.2 and 1 .

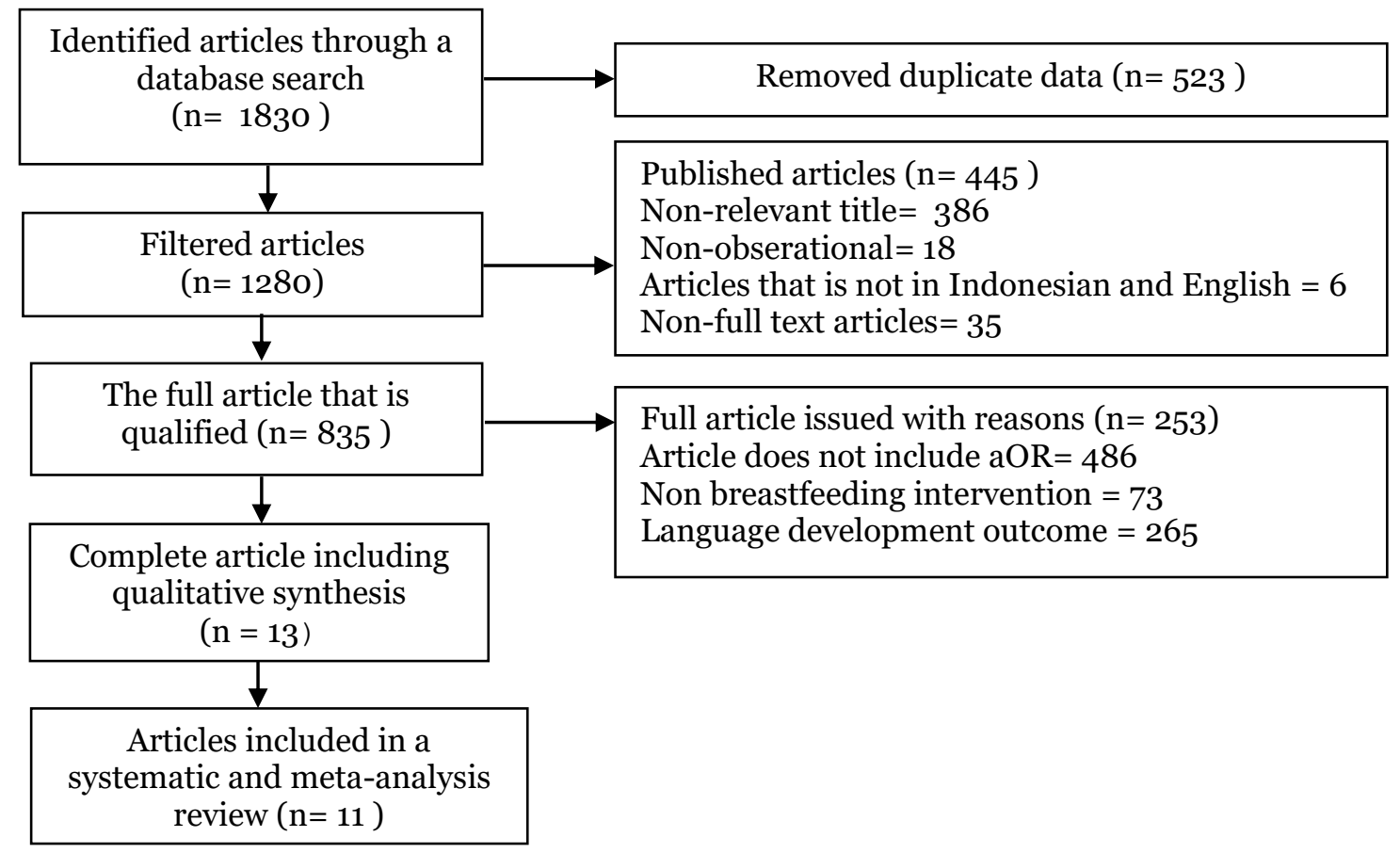

Figure 1. PRISMA Flow Diagram

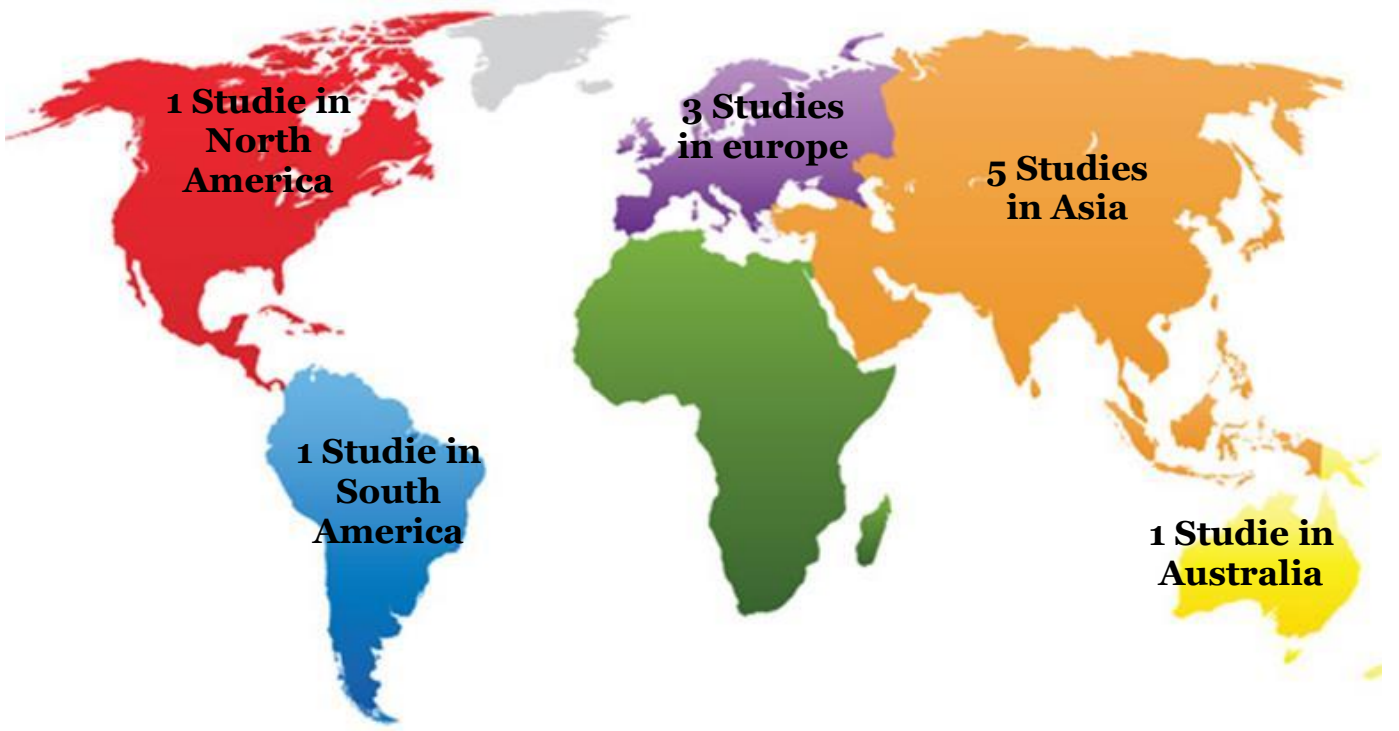

Figure 2. Map of the study area 
Publication

\section{Checklist Questions}

\begin{tabular}{|c|c|c|c|c|c|c|}
\hline \multicolumn{7}{|c|}{ (Author andYear) } \\
\hline $\begin{array}{l}\text { Wendy et } \\
\text { al. (2011) }\end{array}$ & $\begin{array}{l}\text { Quigley et } \\
\text { al. (2012) }\end{array}$ & $\begin{array}{c}\text { Kim and } \\
\text { Choi } \\
(2020)\end{array}$ & $\begin{array}{c}\text { McCrory } \\
\text { and Murray } \\
\text { (2013) }\end{array}$ & $\begin{array}{l}\text { Chiu } \\
\text { et al. } \\
\text { (2011) }\end{array}$ & $\begin{array}{l}\text { Vestergaard } \\
\text { et al. (1999) }\end{array}$ & $\begin{array}{c}\text { Prathanee } \\
\text { et al. } \\
(2007)\end{array}$ \\
\hline 1 & 1 & 1 & 1 & 1 & 1 & 1 \\
\hline 1 & 1 & 1 & 1 & 1 & 1 & 1 \\
\hline 1 & 1 & 1 & 1 & 1 & 1 & 1 \\
\hline 1 & 1 & 1 & 1 & 1 & 1 & 1 \\
\hline 1 & 1 & 1 & 1 & 1 & 1 & 1 \\
\hline 1 & 1 & 1 & 1 & $\mathrm{O}$ & 1 & 1 \\
\hline 1 & 1 & 1 & 1 & 1 & 1 & 1 \\
\hline 1 & 1 & 1 & 1 & 1 & 1 & 1 \\
\hline 1 & 1 & 1 & 1 & 1 & 1 & 1 \\
\hline 1 & 1 & 1 & 1 & 1 & 1 & 1 \\
\hline 1 & 1 & 1 & 1 & 1 & 1 & 1 \\
\hline 1 & 1 & 1 & 1 & 1 & 1 & 1 \\
\hline 12 & 12 & 12 & 12 & 11 & 12 & 12 \\
\hline
\end{tabular}

Does this study address focused and clear issues?

Is the group included in an acceptable way?

Is exposure measured accurately to minimize bias?

Are the results measured accurately to minimize bias?

Have the authors identified all the important confounding factors?

Is the follow-up to the subject of this study complete?

What are the results of this study?

How precise is the result?

Do you believe in the results?

Can the results be applied to the local population?

Are the results of this study consistent with other available evidence?

What are the implications of this study for practice?

Total

Information: Yes $=1, \mathrm{No}=\mathrm{O}$

Table 2. Critical appraisal checklist for cross-sectional study

\begin{tabular}{|c|c|c|c|c|}
\hline \multirow{3}{*}{ Checklist Questions } & \multirow{2}{*}{\multicolumn{4}{|c|}{$\begin{array}{c}\text { Publication } \\
\text { (Author andYear) }\end{array}$}} \\
\hline & & & & \\
\hline & $\begin{array}{c}\text { Barbosa et al } \\
(2009)\end{array}$ & $\begin{array}{c}\text { Sharma et al } \\
\text { (2019) }\end{array}$ & $\begin{array}{c}\text { Iqbal et al } \\
(2017)\end{array}$ & $\begin{array}{c}\text { Dee et al } \\
(2006)\end{array}$ \\
\hline Does this objective clearly address the focus/research problem? & 1 & 1 & 1 & 1 \\
\hline
\end{tabular}


Abida et al./ The Effect of Breast Milk on Child Language

Is the cross-sectional research method suitable for answering research questions?

Is the method of selecting research subjects clearly written?

Does the sampling method create bias (selection)?

Does the research sample taken represent the designated population?

Is the sample size based on pre-study considerations?

Is a satisfactory response achieved?

Are the research instruments valid and reliable?

Is statistical significance assessed?

Are confidence intervals given for the main outcome?

Are there any confounding factors that have not been taken into account?

Are the results applicable to your research?

Total

Information: Yes $=1, \mathrm{No}=\mathrm{O}$

\begin{tabular}{|c|c|c|c|}
\hline 1 & 1 & 1 & 1 \\
\hline O & 1 & O & $\mathrm{O}$ \\
\hline 1 & $\mathrm{O}$ & 1 & $\mathrm{O}$ \\
\hline 1 & 1 & 1 & 1 \\
\hline O & $\mathrm{O}$ & 1 & O \\
\hline 1 & 1 & 1 & 1 \\
\hline 1 & 1 & 1 & 1 \\
\hline 1 & 1 & 1 & 1 \\
\hline 1 & 1 & 1 & 1 \\
\hline O & 1 & 1 & 1 \\
\hline 1 & 1 & 1 & 1 \\
\hline 9 & 10 & 11 & 9 \\
\hline
\end{tabular}

Table 4.Primary study descriptions included in the meta-analysis

\begin{tabular}{|c|c|c|c|c|c|c|c|c|}
\hline $\begin{array}{l}\text { Author } \\
\text { (year) }\end{array}$ & Title & Country & $\begin{array}{l}\text { Study } \\
\text { Design }\end{array}$ & Sample & $\begin{array}{c}\mathbf{P} \\
\underset{\mathbf{n}}{\text { Populatio }} \\
\end{array}$ & $\begin{array}{c}\text { I } \\
\text { Intervention }\end{array}$ & $\begin{array}{c}\text { C } \\
\text { Comparison }\end{array}$ & $\begin{array}{c}\text { O } \\
\text { Outcome }\end{array}$ \\
\hline $\begin{array}{l}\text { Prathanee } \\
\text { et al. } \\
\text { (2009) }\end{array}$ & $\begin{array}{l}\text { Early language delay } \\
\text { and predictor factors } \\
\text { in children aged } 2 \\
\text { years }\end{array}$ & $\begin{array}{l}\text { Bangkok, } \\
\text { Thailand }\end{array}$ & Cohort & 3905 & $\begin{array}{l}\text { Children } \\
\text { aged } 2 \text { years } \\
\text { old }\end{array}$ & $\begin{array}{l}\text { Breastfeeding, } \\
\text { gestational age, gender, } \\
\text { birth order, birth weight, } \\
\text { maternal age, first word } \\
\text { in } 1 \text { year, walking ability } \\
\text { in } 1 \text { year, listening within } \\
5 \text { months, education, } \\
\text { maternal age, maternal } \\
\text { status, maternal } \\
\text { occupation, } \\
\text { socioeconomic, language } \\
\text { number, family } \\
\text { membership, site }\end{array}$ & $\begin{array}{l}\text { Not given } \\
\text { breast milk, } \\
\text { normal birth, } \\
\text { normal weight, } \\
\text { 3rd, 4th and } \\
\text { above birth, } \\
\text { city area }\end{array}$ & $\begin{array}{l}\text { Language } \\
\text { development }\end{array}$ \\
\hline $\begin{array}{l}\text { McCrory } \\
\text { and } \\
\text { Murray }\end{array}$ & $\begin{array}{l}\text { The effeect of } \\
\text { breastfeeding on } \\
\text { neurodevelopment }\end{array}$ & $\begin{array}{l}\text { Newyork, } \\
\text { United } \\
\text { States }\end{array}$ & Cohort & 11134 & $\begin{array}{l}\text { Children } \\
\text { aged } 9 \\
\text { months old }\end{array}$ & $\begin{array}{l}\text { Given breast milk, } \\
\text { gender, birth weight, } \\
\text { gestational age, single }\end{array}$ & $\begin{array}{l}\text { Not given } \\
\text { breast milk }\end{array}$ & $\begin{array}{l}\text { Language } \\
\text { development } \\
\text { (communica- }\end{array}$ \\
\hline
\end{tabular}




\begin{tabular}{|c|c|c|c|c|c|c|c|c|}
\hline $\begin{array}{c}\text { Author } \\
\text { (year) }\end{array}$ & Title & Country & $\begin{array}{l}\text { Study } \\
\text { Design }\end{array}$ & Sample & $\begin{array}{c}\mathbf{P} \\
\begin{array}{c}\text { Populatio } \\
\mathbf{n}\end{array}\end{array}$ & $\begin{array}{c}\text { I } \\
\text { Intervention }\end{array}$ & $\begin{array}{c}\text { C } \\
\text { Comparison }\end{array}$ & $\begin{array}{c}\text { O } \\
\text { Outcome }\end{array}$ \\
\hline (2013) & in infaancy & & & & & $\begin{array}{l}\text { status, maternal age, } \\
\text { ethnicity, social class, } \\
\text { maternal education and } \\
\text { smoking status }\end{array}$ & & tion) \\
\hline $\begin{array}{l}\text { Min and } \\
\text { Choi } \\
\text { (2020) }\end{array}$ & $\begin{array}{l}\text { Association between } \\
\text { breastfeeding and } \\
\text { cognitive function in } \\
\text { children from early } \\
\text { childhood to school } \\
\text { age: a prospective } \\
\text { birth cohort study }\end{array}$ & $\begin{array}{l}\text { Cheonan, } \\
\text { Korea }\end{array}$ & Cohort & 1752 & $\begin{array}{l}\text { Children } \\
\text { aged } 3 \text { years } \\
\text { old }\end{array}$ & $\begin{array}{l}\text { Given breast milk, } \\
\text { gender, gestational age, } \\
\text { birth weight, income, } \\
\text { parental education, age } \\
\text { in each assessment }\end{array}$ & $\begin{array}{l}\text { Not given } \\
\text { breast milk }\end{array}$ & $\begin{array}{l}\text { Intellectual } \\
\text { development } \\
\text { (language, } \\
\text { gross and fine } \\
\text { motives, } \\
\text { personal, } \\
\text { social, problem } \\
\text { solving) }\end{array}$ \\
\hline $\begin{array}{l}\text { Quigley et } \\
\text { al (2011) }\end{array}$ & $\begin{array}{l}\text { Breastfeeding is } \\
\text { associated with } \\
\text { improved child } \\
\text { cognitive develop- } \\
\text { ment: A popolation } \\
\text { based cohort study }\end{array}$ & $\begin{array}{l}\text { Newyork, } \\
\text { United } \\
\text { States }\end{array}$ & Cohort & 11879 & $\begin{array}{l}\text { Children } \\
\text { aged } 5 \text { years } \\
\text { old }\end{array}$ & $\begin{array}{l}\text { Duration of } \\
\text { breastfeeding }\end{array}$ & $\begin{array}{l}\text { Not given } \\
\text { breast milk }\end{array}$ & $\begin{array}{l}\text { Cognitive } \\
\text { development, } \\
\text { language } \\
\text { development } \\
\text { (vocabulary) }\end{array}$ \\
\hline $\begin{array}{l}\text { Vestergaar } \\
\text { d et al } \\
(1999)\end{array}$ & $\begin{array}{l}\text { Duration of breast- } \\
\text { feeding and develop- } \\
\text { ment milestone } \\
\text { during the latter half } \\
\text { of infancy }\end{array}$ & $\begin{array}{l}\text { Denmark, } \\
\text { Eropa }\end{array}$ & Cohort & 250000 & $\begin{array}{l}\text { Children } \\
\text { aged } \\
\text { 8months } \\
\text { old }\end{array}$ & Exclusive breastfeeding & $\begin{array}{l}\text { Not given } \\
\text { breast milk }\end{array}$ & $\begin{array}{l}\text { Development } \\
\text { of milestones } \\
\text { (language, } \\
\text { gross motor } \\
\text { skills, fine } \\
\text { motor skills) }\end{array}$ \\
\hline $\begin{array}{l}\text { Chiu et al } \\
\text { (2011) }\end{array}$ & $\begin{array}{l}\text { Duration of breast } \\
\text { feeding and risk of } \\
\text { development delay } \\
\text { in Taiwanese child- } \\
\text { ren: a nationwide } \\
\text { birth cohort study }\end{array}$ & $\begin{array}{l}\text { Taipei, } \\
\text { Taiwan, } \\
\text { Asia }\end{array}$ & Cohort & 14621 & $\begin{array}{l}\text { Children } \\
\text { aged } 15 \text { to } \\
18 \text { months } \\
\text { old }\end{array}$ & $\begin{array}{l}\text { Duration of } \\
\text { breastfeeding, gross } \\
\text { motor skills, fine motor } \\
\text { skills, language, social }\end{array}$ & $\begin{array}{l}\text { Never given } \\
\text { breast milk }\end{array}$ & $\begin{array}{l}\text { Language } \\
\text { development }\end{array}$ \\
\hline $\begin{array}{l}\text { Oddy et al } \\
\text { (2011) }\end{array}$ & $\begin{array}{l}\text { Breastfeeding and } \\
\text { early child } \\
\text { development: a } \\
\text { prospective cohort }\end{array}$ & $\begin{array}{l}\text { Perth, } \\
\text { Australia }\end{array}$ & Cohort & 2868 & $\begin{array}{l}\text { Children } \\
\text { aged } 3 \text { and } \\
1,2 \text { years } \\
\text { old }\end{array}$ & $\begin{array}{l}\text { Breastfeeding less than } 4 \\
\text { months and more than } 4 \\
\text { months, gross motor } \\
\text { skills, fine motor skills, }\end{array}$ & $\begin{array}{l}\text { Have never } \\
\text { been given } \\
\text { breast milk or } \\
\text { given breast }\end{array}$ & $\begin{array}{l}\text { Child } \\
\text { development } \\
\text { (language, } \\
\text { gross motor }\end{array}$ \\
\hline
\end{tabular}


Abida et al./ The Effect of Breast Milk on Child Language

\begin{tabular}{|c|c|c|c|c|c|c|c|c|}
\hline $\begin{array}{l}\text { Author } \\
\text { (year) }\end{array}$ & Title & Country & $\begin{array}{l}\text { Study } \\
\text { Design }\end{array}$ & Sample & $\underset{\mathbf{n}}{\mathbf{P}}$ & $\stackrel{\text { I }}{\text { Intervention }}$ & $\begin{array}{c}\mathrm{C} \\
\text { Comparison }\end{array}$ & $\begin{array}{c}\text { O } \\
\text { Outcome }\end{array}$ \\
\hline $\begin{array}{l}\text { Sharma et } \\
\text { al (2019) }\end{array}$ & $\begin{array}{l}\text { Asessment of risk } \\
\text { factors for develop- } \\
\text { mental delays } \\
\text { among children in a } \\
\text { rural communityof } \\
\text { north India: a cross- } \\
\text { sectional study }\end{array}$ & India, Asia & $\begin{array}{l}\text { Cross- } \\
\text { secctiona } \\
\text { l }\end{array}$ & 450 & $\begin{array}{l}\text { Children } \\
\text { aged } 2 \\
\text { monthsto6y } \\
\text { ears old }\end{array}$ & $\begin{array}{l}\text { adaptation, language } \\
\text { (communication), social }\end{array}$ & $\begin{array}{l}\text { milk for less } \\
\text { than } 4 \text { months } \\
\text { and more than } \\
4 \text { months } \\
\text { Not given } \\
\text { breast milk }\end{array}$ & $\begin{array}{l}\text { skills, fine } \\
\text { motor skills, } \\
\text { adaptability, } \\
\text { social } \\
\text { Speech, social } \\
\text { and cognitive } \\
\text { language } \\
\text { development }\end{array}$ \\
\hline $\begin{array}{l}\text { Lee et al } \\
(2007)\end{array}$ & $\begin{array}{l}\text { Associations } \\
\text { between breastfeed- } \\
\text { ing practices and } \\
\text { young children's } \\
\text { language and motor } \\
\text { skill development }\end{array}$ & $\begin{array}{l}\text { Maryland. } \\
\text { United } \\
\text { States }\end{array}$ & $\begin{array}{l}\text { Cross- } \\
\text { secctiona } \\
\text { l }\end{array}$ & 22399 & $\begin{array}{l}\text { Children } \\
\text { aged 1oto } \\
\text { 71months } \\
\text { old }\end{array}$ & Given breast milk & $\begin{array}{l}\text { Not given } \\
\text { breast milk }\end{array}$ & $\begin{array}{l}\text { Language } \\
\text { Development } \\
\text { and Motor } \\
\text { Development }\end{array}$ \\
\hline $\begin{array}{l}\text { Barbosa et } \\
\text { al (2009) }\end{array}$ & $\begin{array}{l}\text { The relationship of } \\
\text { bottle feeding and } \\
\text { other sucking beha- } \\
\text { viors with speech } \\
\text { disorders in Patago- } \\
\text { nian preschoolers }\end{array}$ & $\begin{array}{l}\text { Wasshingt } \\
\text { on , } \\
\text { United } \\
\text { States }\end{array}$ & $\begin{array}{l}\text { Cross- } \\
\text { secctiona } \\
1\end{array}$ & 128 & $\begin{array}{l}\text { Children } \\
\text { aged } \\
\text { 3to5years } \\
\text { old }\end{array}$ & Given breast milk & $\begin{array}{l}\text { Not given } \\
\text { breast milk }\end{array}$ & $\begin{array}{l}\text { Speech } \\
\text { language } \\
\text { development }\end{array}$ \\
\hline $\begin{array}{l}\text { Iqbal et al } \\
(2017)\end{array}$ & $\begin{array}{l}\text { The effect of breast- } \\
\text { feeding on the cogni- } \\
\text { tive development of } \\
\text { children under } 3 \\
\text { years of age: result } \\
\text { of balochistan early } \\
\text { childhood develop- } \\
\text { mental project }\end{array}$ & $\begin{array}{l}\text { Pakistan, } \\
\text { Asia }\end{array}$ & $\begin{array}{l}\text { Cross- } \\
\text { secctiona } \\
1\end{array}$ & 604 & $\begin{array}{l}\text { Children } \\
\text { under } 3 \\
\text { years old }\end{array}$ & Given breast milk & $\begin{array}{l}\text { Not given } \\
\text { breast milk }\end{array}$ & $\begin{array}{l}\text { Language } \\
\text { development } \\
\text { and cognitive } \\
\text { development }\end{array}$ \\
\hline
\end{tabular}


Abida et al./ The Effect of Breast Milk on Child Language

1. Breastfeeding on Language Development

a. Forest Plot

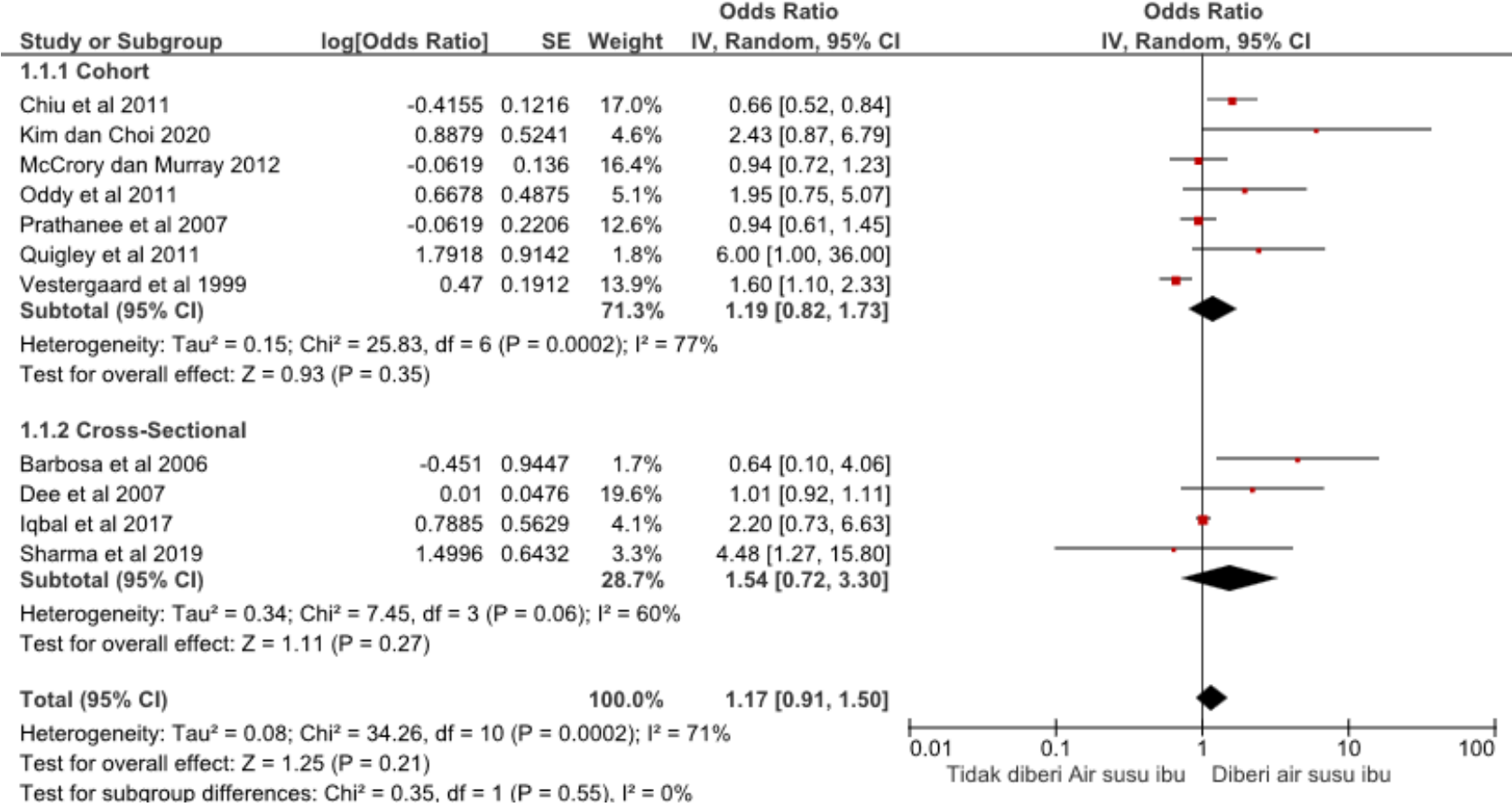

\section{Figure 4. Funnel Plot of the effect of breastfeeding on language development}

\section{b. Funnel Plot}

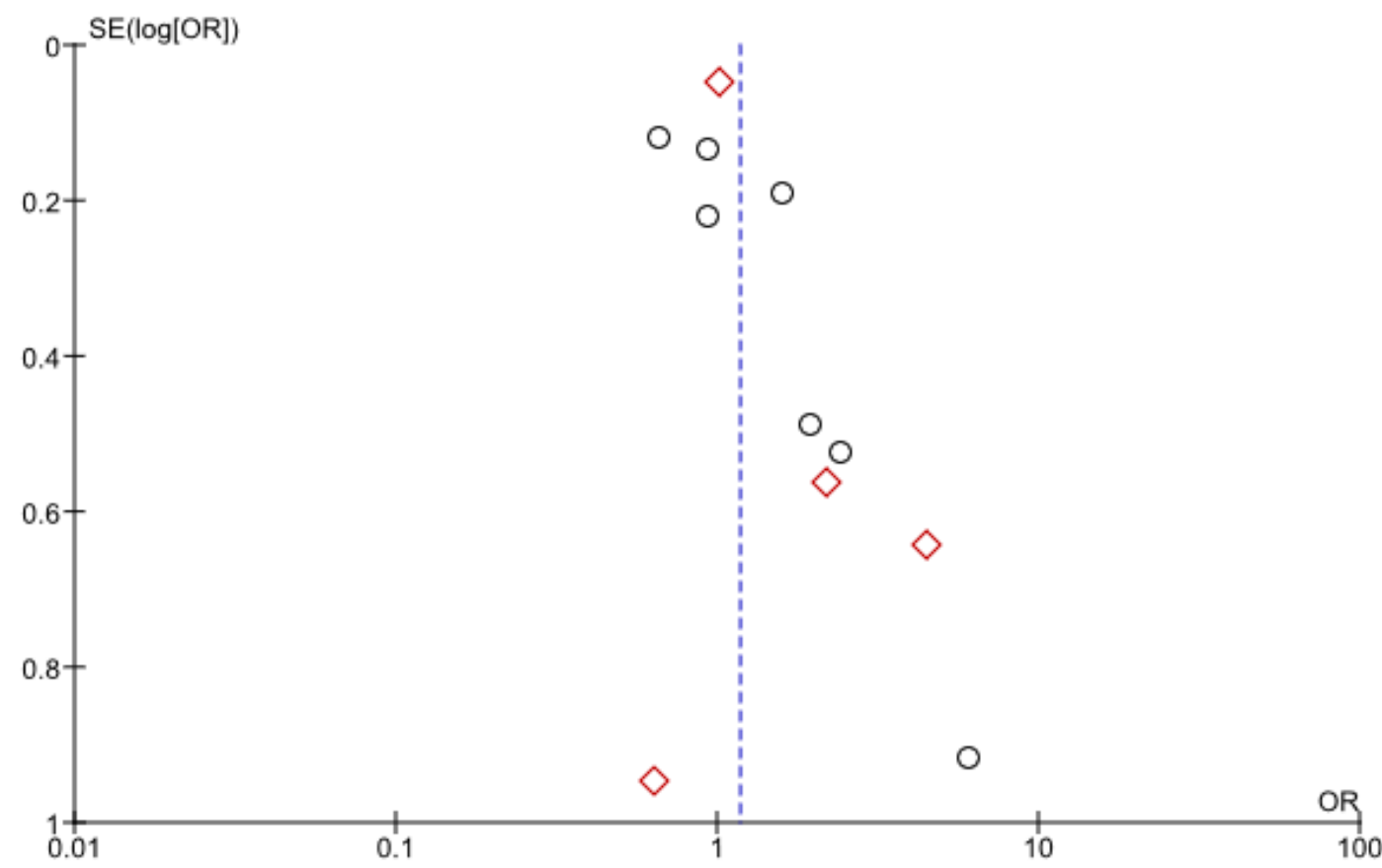

$\checkmark$ Cohort $\diamond$ Cross-Sectional

Figure 4. Funnel Plot of the effect of breastfeeding on language development 


\section{DISCUSSION}

The systematic and meta-analysis study raised the theme of breastfeeding with children's language development. The study discussed data on language development because language is an important developmental component and is one of the main milestones in child development.

This systematic review and metaanalysis study used research that controls the confounding factor which can be seen from the study inclusion requirements, namely multivariate analysis and the statistical result reported was the adjusted odd ratio (aOR).

Estimates of the combined effect of breastfeeding on language development in children were processed using the RevMan 5.3 application with the generic inverse variance method. The results of the systematic study and meta-analysis were presented in the form of a forest plot and a funnel plot. The forest plot provided an overview of information from each of the studies examined in the meta-analysis, and estimates of the overall results (Murti, 2018).

The funnel plot showed the amount of variation visually (heterogeneity) (Akobeng, 2005 in Murti, 2018). The funnel plot showed the relationship between the effect size of the study and the sample size of the various studies under study, which can be measured in a number of different ways (Murti, 2018).

\section{The effect of breastfeeding on language development}

There are 11 observational study articles consisting of 7 cohort studies and 4 crosssectional studies as a source of metaanalysis of the effect of breastfeeding on language development in children.

Analyzes were performed with subgroups of each observational study design. The meta-analysis results of the cohort study showed that breastfeeding increased children's language development by 1.19 times higher compared to language development of children who were not breastfed (aOR 1.19, 95\% CI 0.82-1.73, p = 0.35. ). Meanwhile, the meta-analysis of crosssectional studies showed that breastfeeding can improve children's language development by 1.54 times higher compared to language development of children who were not breastfed(aOR 1.54, CI 95\% 0.72 - 3 . $30, \mathrm{p}=0.27$ ).

This is supported by Rosidi et al. (2019), which stated that children who receive breastmilk exclusively get sufficient energy intake so that language development increases.

This study is in line with study done by Blomkvist et al. (2019) which stated that breast milk is related to children's neurodevelopment because it contains nutrients needed by the brain, such as carbohydrates, proteins, vitamins, minerals, lipids and minerals.

Another study by Cai et al. (2019) stated that breastfeeding showed significant benefits for memory development and language development in children. Children who are given breast milk have better comprehension language skills and oral language skills compared to children who do not get breast milk.

Jinliuxing (2020) stated that breastfeeding is very important for the development of the baby, especially for communication. Another benefit of breast milk in this study is for the development of problem-solving skills and children's social interactions. Babies who are given breast milk have much better development in their communication. Babies who get formula milk have a higher risk of developing developmental delays than babies who are breastfed. 
This study is strengthened by the research of Zulaikha and Rizqi (2017). From this study, it was found that a history of breastfeeding predicts the level of language development of children. Child nutrition is very important, especially in the early stages of development, which is the age of 0-24 months old, and it is a golden period for child development and growth.

\section{AUTHOR CONTRIBUTION}

Liza is the main researcher who selected topics, searched and collected study data. Bhisma Murti and Hanung Prasetya had a role in analyzing data and reviewing study documents.

\section{CONFLICT OF INTEREST}

There was no conflict of interest.

\section{FUNDING AND SPONSORSHIP}

This study used personal fund of the main researcher.

\section{ACKNOWLEDGEMENT}

We are very thankful to the database providers of PubMed, Google Scholar and Springer Link.

\section{REFERENCE}

ASHA (2020). Language in Brief. American Speech and Hearing Association

Blomkvist EAM, Hillesund ER, Helland SH, Simhan I, Øverby NC (2019). Diet and neurodevelopmental score in a sample of one-year-old children-a cross-sectional study. Nutr Res. (11): 1-12. https://doi.org/10.3390/nu11071676.

Cai S, Pang WW, Low YL, Sim LW, Sam SC, Bruntraeger MB, Wong EQ, Fok D, et al. (2014). Infant feeding effects on early neurocognitive developmentin Asian children 1-4. Am J Clin Nutr.
(101):326-36. https://doi.org/10.3945/ajen.114.095414.

Dee DL, Li R, Lee LC, Grummer-Strawn LM (2007). Associations between breastfeeding practices and young children's languageand motor skill development. Am Acad Pediatr. https://doi.org/10. 1542/peds.2006-2089n.

Iqbal M, Rafique G, Ali SA (2017). The effect of breastfeeding on the cognitive and language development of children under 3 years of age: Results of 'Balochistan-early childhood development project. J Gen Prat. 5(305). https://dx.doi.org/10.3346\%2Fjkms. 2016.31.4.579.

Kementerian Kesehatan RI (2018). Paparan Hasil Utama Riset Kesehatan Dasar (Description of Main Results of Basic Health Research).

Kim MK, Choi JW (2020). Associations between breastfeeding andcognitive function in children from early childhood to school age: a prospectivebirth cohort study. Int Breastfeed J. 15: 83. https://doi.org/10.1186/s13006-020o0326-4.

McCrory C, Murray A (2013). The effect of breastfeeding on neuro development in infancy. Matern Child Health J. 17: 1680-1688. https://doi.org/10.1007/s10995-012-1182-9.

Murti B (2018). Prinsip dan Metode Riset Epidemiologi. Edisi ke 5 (Epidemiological Research Principles and $\mathrm{Me}$ thods. 5th edition). Surakarta: Program Studi Ilmu Kesehatan Masyarakat.

Oddy WH, Robinson M, Kendall GE, Li J, Zubrick SR, Stanley FJ (2011). Breastfeeding and early child development: a prospective cohort study. Acta Pædiatrica. (100): 992-999. https://doi.org/10.1111/j.1651-2227.2011.02199.x 
Prathanee B, Purdy SC, Thinkhamrop B, Chaimay B, Ruangdaraganon N, Mosuwan L, Phuphaibul R (2007). Early language delay and predictive factors in children aged 2 years. J Med Assoc Thai. 92(7):930-8. PMID: 19626813.

Quigley MA, Hockley C, Carson C, Kelly Y, Renfrew M, Sacker A (2011). Breastfeeding is associated with improved child cognitive development: A population-based cohort study. J Pediatr. (160):25-32. https://doi.org/10.1016/j.jpeds.2011.06.035.

Rosidi A, Bening S, Sulistyowati E, Hunandar E, Sunarto, Wijaningsih W (2019). Inadequate energy intake as a risk factor to developmental delay of preschool aged children. Scientific Journal. 15: 1-5.

Sharma N, Masood J, Singh SN, Ahmad N, Mishra P, Singh S, Bhattacharya S (2020). Assessment of risk factors for developmental delays among children in a rural community of North India: A cross-sectional study. J Edu Health
Promot. 8 (112). https://dx.doi.org/10.4103\%2Fjehp.jehp_405_18.

Vestergaard M, Obel C, Henriksen TB, Sorensen HT, Skajaa E dan Ostergaard J (1999). Duration of breastfeeding and developmental milestone during the latter of infancy. Int $J$ Paediatr. (88): 1327-32. https://doi.org/10.1080/o80352599750030022.

Yusuf (2004). Psikologi perkembangan anak dan remaja (Psychology of Children and Adolescents Development). Bandung: Rosda.

Zulaikha F, Rizqi NFS (2018). Hubungan pemberian asi eksklusif dengan perkembangan bahasa anak usia prasekolah di paud wilayah kerja puskesmas mangkupalas samarinda tahun 2017 (The relationship of exclusive breastfeeding with the language development of preschool children in the paud working area of the Mangkupalas Health Center, Samarinda in 2017). Public Health J. (6)1. 